\title{
An Anthropology of Historic Foods in Japan, China and Korea
}

Bok-rae Kim

Andong National University, Andong 36729, South Korea

\begin{abstract}
This paper is divided into three subjects: Japanese Genghis Khan, Chinese tofu and Korean bibimbap (mixed rice with vegetables). It will be a cross-cultural and comparative research on historic foods among three countries (Japan, China, and Korea), in relation to national culinary identity.
\end{abstract}

Key words: Japanese Genghis Khan, Chinese tofu, Korean bibimbap, anthropology of food, historic food.

\section{Introduction}

The traditional foods are developed in a way that was different from prevailing paradigm, which we call "modernity". However, we want to believe that they existed from the remote ages of antiquity and still exist today without any interruption. Giving a national identity to food is considered as part of the great causes, if not struggles, for securing the rights to some specific foods among nations and races. But we do not eat food in our daily life in intensively arguing on history or legitimacy. Our pleasure of eating can be doubled according to each individual's taste or in search of a new taste. Thus, we do not need to tarnish the proper function of food on the pretext of legitimacy.

This paper is divided into three subjects: Japanese Genghis Khan, Chinese tofu and Korean bibimbap (mixed rice with vegetables). It will be a cross-cultural and comparative research on historic foods among three countries (Japan, China, and Korea), in relation to national culinary identity.

\section{Japanese Cuisine Called "Genghis Khan"}

For years Hokkaido was unique in Japan for its high consumption of mutton. Here, Genghis Khan became a local specialty, cooked atop a unique dome-shaped

Corresponding author: Bok-rae Kim, Ph.D., professor, research field: comparative research Europe vs. East Asia. grill-reminiscent of a Mongolian warrior's helmet - which may have inspired the Genghis Khan moniker. Nowadays, Hokkaido population of 5.63 million people have an expenditure of US\$ 12.25 (\$1= $¥ 100$ ) per person per year on Genghis Khan Cuisine [1].

\subsection{The Origin of Genghis Khan}

Since the Meiji reform the wool has been used for the military clothing in Japan at the end of the 19th century. In Japan sheep were not brought up, so the wool was imported from Russia and China. The year 1914 witnessed the outbreak of the First World War. Then, it was not easy to import wool. In 1918 Japanese government enforced a policy called "the plan of one hundred sheep heads" to attain a self-sufficiency of the wool. Hereafter, sheep ranches were run in Hokkaido, Sapporo, Sikoku, etc. But sheep ranch owners have been grappling with the problem of handling a flock of old sheep which became "useless". They were obliged to sell mutton cheap.

Before the Meiji reform Japanese ruling classes did not eat meat openly, because of religious restrictions: Buddhism and Shinto (natural spirituality of Japan). ${ }^{1}$

\footnotetext{
1 The aversion to meat-eating during the Edo period was primarily influenced by the Buddhist notion of transmigration and compassion for living things, coupled with the Shinto idea of kegare, or impurity.
} 
Beef was a powerful symbol of death and dirtiness. This did not mean, however, that meat eating was totally banned in Japan. However, a lack of animal breeding for meat kept its consumption very low. In large cities such as Edo (modern day Tokyo) and Osaka, Japanese ate meat under the pretext of medicinal eating (kusurigui) and referred to it with euphemisms such as "kuroyaki" (dark baked), "momji" (maple) or "momonga" (flying squirrel), and "yamakujira" (mountain whale). In this way, on the record, Japanese did not eat meat, thereby avoiding potential defilement [2]. However, after the Meiji, there was a general awareness that Japanese people should eat meat like Westerners for the purpose of creating a modern enlightened civilization. Despite the contempt of meat eating in Japan, the association of meat with Westerners' diet pattern began to bolster its image.

From that time, various kinds of meat foods have been developed in Japan. A beef stew called "gyu-nabe" was the most popular among them. By the late 1870s Tokyo counted several hundred establishments that were serving beef stew [3]. The "nabe" in Japanese means one-pot cooking into which you can throw "everything". Of course, there is a mutton stew called "yo-nabe". The mutton is too cheap to throw it away. Thus, it played a great role in the meat consumption among the poor. This is the background of birth of the Japanese cuisine called "Genghis Khan.",

\subsection{The Image of Rich Nation and Strong Army}

Why do Japanese people designate "yo-nabe" in the name of Genghis Khan? In 1931, Japan founded a puppet regime in Manchuria. Japanese soldiers and many civilians also for business purpose stayed in China. In 1910s, the opinion that the Japanese were

\footnotetext{
${ }^{2}$ An article entitled "Genghis Khan Story" was mentioned in Hokkaido newspaper (January 7-11, 2003). It may be somewhat misleading to call this dish Genghis Khan, after the heroic Mongolian warrior-king, for it didn't come from Mongolia but from China.
}

the descendants of the horse nomads won the broad support. Their ancestors came on a horse to Japanese Archipelago from Siberia. This view was properly used to justify Japanese invasion into Korea and continental China. Japanese modernists (advocates of Western-styled modernity) insisted that the Japanese should learn about the West, and that they should become superior Europeans instead of being inferior Asians [4]. ${ }^{3}$ However, Europeans considered Japan as a part of Asia. The stress from its inner contradiction decisively seemed to form the background of naming the yo-nabe "Genghis Khan" in early 1930s. Since 1920s, Japan has advanced into the northeast China for the development of Manchuria. Japanese people in the vast continent of China were really struck with the epic of Genghis Khan who invaded even Europe! The series of Hokkaido newspaper mentioned that the image of rich nation and strong army in Japanese modernity goes well with that of the Genghis Khan cuisine. The reporter added that he feels as if Genghis Khan who once commanded the Eurasian continent embraces himself, whenever he eats the oily Genghis Khan food. Most mutton meat has heavy and unpleasant odor. Thus, it is necessary to develop a recipe for resolving it. In Hokkaido people preserved mutton in fruit juices (apple, onion and mandarin, etc.) during one day and grilles it on charcoal fire. It was sweet-flavored. In 1930s, some restaurants specializing in mutton in Tokyo preserved mutton in salt. It was salted. On the other hand, the mutton was broiled in an iron casserole in Kochi Prefecture, Shikoku. This iron casserole was first introduced into a Genghis Khan restaurant in Kochi. According to the Hokkaido newspaper, it was Yoshimoto Kenji who developed this Genghis Khan casserole. In 1939 he went to Manchuria for business, but all his attempts met with failure. At the end of World War, he was detained in China. In 1949 he returned to his

\footnotetext{
3 Japan was to avoid being confused with China or Asia in Western eyes and instead elevate its status in the international arena through extensive Westernization. Western-style dining became an integral part of the project.
} 
hometown Kochi. On the basis of his experience in Manchuria, he opened a restaurant selling a cheap mutton food called "Genghis Khan nabe" in 1953.

Genghis Khan cuisine has never been a common feature in the Japanese diet beyond Hokkaido. Until 1950s, the mutton was a well-timed food to resolve a postwar poverty. But in 1960s Japanese people experiencing a sweet taste of economic recovery had no longer any reason to consume the mutton once considered as lower category of meat. Beef and pork pleased their palate. It is natural that mutton consumption heavily relying on more than $99 \%$ of its imports decreased in Japan.

It was difficult to find Genghis Khan cuisine in Japan, except Hokkaido or Kochi. However, in recent years, a more sophisticated distribution system for chilled meat - and broad changes in consumer tastes - have landed some of the world's freshest, most delicate-tasting lamb and mutton on menus across the country. According to one Genghis Khan restaurant in Tokyo, the number of restaurants specializing in Genghis Khan grew from only about 20 in 2004 to some 200 today. No doubt about it: Genghis Khan is no longer a purely Hokkaido phenomenon. Why the sudden surge in popularity? Like so many trends in Japan, this one has been driven by young women often trendsetters who are aware of Genghis Khan's high levels of L-carnitine, an amino acid known to burn fat and improve energy, found in many meats and dairy foods [5]. ${ }^{4}$ Nowadays, Genghis Khan plays the role of locomotives in attracting a lock of food tourists in Hokkaido, putting away the echoes of its past "rich nation, strong army model".

\section{Tofu: A Great Invention of Northern China}

There have been many attempts to put historical mysteries of one nation into a specific food, while

\footnotetext{
4 Japan's newest Genghis Khan restaurants are attracting younger customers with chic interior design that only enhances the food's typically low price, which is relatively inexpensive at around 1,000 yen (US\$9) per serving.
}

reminding us of its origin or history. To give an example, we can enumerate the origin of tofu (bean curd) as a pre-modern cultural product. A Japanese writer and translator Haruki Murakami who eats tofu at every meal is a whimsical devotee in saying "tofu is the best food after sex." China is number one, Japan is second, and Korea is third in the per capita consumption of tofu. The famous six-pack of Shaolin temple's monks was made of tofu, wasn't it? Tofu that contains much vegetable protein and calcium is now for the champion of diet, anti-aging, and anti-osteoporosis. Tofu can be compared to a "beauty of a thousand faces", because it has a wide ranging variety of dishes from a simple tofu to the haute cuisine with luxury caviar and whipping cream, according to inexhaustible recipes. During the Chosun period (1392-1910) the tofu was called "po (泡: foam)" in Korean. The Korean metaphor of po reminds us of a foamy soymilk. When boiling soymilk, bubbles form on the surface. The name of Greek goddess of beauty "Aphrodite" is a compound word: aphros $($ foam $)+$ dite (female suffix). Hesiod connects it with á $\varphi \rho o ́ \varsigma$ (aphros) "foam", interpreting it as "risen from the foam". Two seem related somehow in their metaphor of foam, but storytelling the birth of tofu is more various than that of Aphrodite.

\subsection{The Origin of Tofu}

There are at least four theories concerning the origin of tofu in China. The first "Liu An" theory states that tofu was developed by Liu An, King of Huai-nan, who lived in the southeast part of north China from 179-122 BC. The second "accidental" coagulation theory states that tofu was developed quite by accident, probably prior to $\mathrm{AD} 600$, when someone, probably in northern China, seasoned a pureed soybean soup with unrefined sea salt containing natural nigari and noticed that curds formed. The third "Indian import" theory states that tofu, or at least the basic method for its preparation, was imported from the dairying tribes or perhaps the Buddhist monks of India. The fourth "Mongolian 
import" theory states that the basic method for making tofu was adapted from the cheese-making process learned from milk-drinking Mongolian tribes living along the northern border of China. The third and fourth theories suggest that, since the Chinese did not generally raise cows or goats for milk, they were probably not familiar initially with the curding process. They may have learned it from either the Indians far to the southwest or from the nomadic Mongolian tribes just to the north, both of whom practiced dairying and made curds, cheeses, and fermented milk products. While the last three of these four theories all seem reasonable, there is, unfortunately, relatively little evidence to support any of them, except the Mongolian import theory [6].

The earliest existing document containing mention of the term “doufu” is the Ching I Lu (清異錄, Seiiroku in Japanese), written by Tao Gu (陶穀: 903-970) in about 950 AD [7]. ${ }^{5}$ He compiled episodes handed down by tradition. He stated that tofu was developed by Liu An. Liu An is a grandson of Liu Bang, the first emperor of the Han dynasty.

Thenceforth, many books have mentioned that tofu was his invention. If the tofu was invented during the Han dynasty, it should have appeared in literature after that time. However there was no literature which recorded something akin to tofu before the Ching $I \mathrm{Lu}$ of Tao ku in question. Furthermore, in Chinese history, important inventions were often attributed to important leaders and figures of the time. Thus, the authenticity of his book seems questionable.

From our contemporary prospects the process of making tofu seems very easy, but thousand years ago the situation was quite different. In contrast to Genghis Khan cuisine, tofu needs some special efforts to invent. Tofu is made by coagulating water soluble soybean proteins with salt water, lime water or glucose, etc. A Korean anthropologist Young-ha Joo thinks that the invention of tofu was closely related to

\footnotetext{
5 Shinoda Osamu found that this book called Seiiroku in Japanese or Chungi-rok in Korean was the world's earliest document to mention tofu.
}

nomad people living in northern Zhongyuan or the Central Plain of China (中原). The nomad people made many lactic acid fermented foods like cheese. Since Tang dynasty these nomad people have advanced into the southern part of Beijing. During the Five Dynasty in particular, ${ }^{6}$ they took control of Northern China. Nevertheless, it does not mean that all Zhongyuan people moved into the south. After all, the actual northern China was the linkage place where nomadic and agricultural people could meet together. The agricultural people made soy sauce or soybean paste using yellow soybeans. It was nomadic people who taught them how to extract juice from soybean by boiling and grinding it. It was the soy milk. If you drink soy milk without salt, it smells fishy. The period where the tofu became popular corresponds to when Song Dynasty gained control of Northern China. For this reason, I guess, the tofu appeared for the first time in the literature during the Northern Song Dynasty. After 12th century the tofu was so often mentioned in many Chinese literatures.

The well-known Japanese food historian and sinologist Shinoda Osamu (1899 1978) developed that tofu was invented in China, but not in ancient times. Probably in the middle of the Tang dynasty (618-906), and it became popular in the middle of Song dynasty (960-1279) [8, 9]. ${ }^{7}$ If so, why did Tao $\mathrm{Ku}$ in Northern Song period attribute the origin of tofu into Han Dynasty? Tao Ku was born in Sansi province. He was a civil servant in the Later Jin of the Five Dynasties (936-946). His family name was Tang, he changed it into Tao, because it was the same as the emperor's name of the Later Jin. As for him, the Northern Song dynasty founded by Zhongyuan people was legitimate, but he expressed serious doubts about the legitimacy of many countries before Song. He

\footnotetext{
${ }^{6}$ The time from 907-960 A.D. is called the Five Dynasties.

${ }^{7}$ In the 1980s, Chinese researchers found a tomb mural incised on a stone slab from the Eastern/Later Han dynasty (25-220) that clearly shows a tofu (or a prototype of tofu) being made. However, no one is quite sure in the history of food relying on the paucity or lack of documents, even with the archeological excavations.
} 
wanted to link the legitimacy of Song Dynasty to that of Han Dynasty. Thus he seemed to give the honor of inventing tofu to Liu An, grandson of Han Dynasty's founder. Liu An was not only a pro-reform Taoist, but also an advocate for local self-governance under the Han's Confucian centralized, bureaucratic rule. Many tales of tofu origin surrounding him are probably due to his liberal characters and ideas. Liu An became an unexpected inventor of tofu-as a fiasco of the elixir of life/youth - and his hometown, Shouxian County of Anhui Province, has been dubbed as "hometown of tofu".

According to Eric Hobsbawm in The Invention of Tradition, many of the mass, public traditions in various societies of the world are well-crafted (invented) constructs of the 18th/19th centuries, and are not as ancient or immemorial as they are generally believed to be [10]. It means that modern nation-states which appeared in the middle of the 19th century have developed the construction of the past and the invention of traditions to secure their legitimacy. The discussion on the origin of tofu may be also related to "making tradition" during the pre-modern period before the emergence of nation-state, in order to give a legitimacy to Song dynasty established by Han Chinese people in Zhongyuan.

Chinese people excited about successful economic growth and Beijing Olympic Games have actively stated that plenty of foods in the world may have originated from China. A Chinese archeologist Ren-Xiang Wang (王仁湘) insisted that the yeast to make rice wine was invented in China, and that Chinese-styled wine making was well accomplished during Tang dynasty. During Tang dynasty China imported small quantities of wine from Western Regions (西域). Thus, Tang Taizong (唐太宗) (626-649) took a direct hand in wine making. Finally, he succeeded in making wine, but that is all. Wine was temporarily in vogue after having satisfied emperor's personal need, but never was widely liked by Chinese people as national liquor. Joseph Needham
(1900-1995), a British academic and sinologist known for his research and writing on the history of Chinese science, said that all great inventions of ancient China were used as convenient instruments to maintain the emperor's power. Tang wine was also a science for emperor. A swallow does not make a spring.

\section{Korean Bibimbap (Boiled Rice with Assorted Mixtures)}

Korean foods Japanese like are bibimbap (boiled rice with assorted mixtures) and bulgogi (grilled beef). Until 1990s, Japanese people compared mixed bibimbap to a trash. The word "bibimbap" literally means mixed meal. It is not a simple menu. In Japan different ingredients are never mixed together thoroughly just before eating. Japanese people say it is really beyond their imagination; therefore, they consider bibim (mixing) as a great act of destroying a form. The reason is that "a taste of the original material" is the best in Japanese food culture. Thus, soy sauce, mustard and other spices are accepted only on the condition that they do not touch with one another the taste of the original material. Raw fish should taste raw fish, vegetables should taste vegetables, and meat should taste meat. This logic of raw fish in Japanese food and culture can be also applied to religion.

It can be said that Japanese culture is formed by both Shinto and Buddhism. One of the essential characteristics of Shinto is to emphasize particularity over universality. The Shinto has historically opened the door for the Japanese people to be practical and accepting of foreign cultures and healing methods associated with those other cultures. Japan has over 8 million gods nationwide. We can meet many shrines everywhere at each village. While one shrine is famous for traffic safety, another shrine is wonderfully efficacious for admission to the university. Japanese people crowd into these renowned local shrines.

We can also understand Japanese Buddhism under the same context. When Buddhism was introduced 
into Japan in A.D. 538 from Baek-je (Korean Kingdom), the Japanese Emperor considered it as one of many gods in the neighboring countries. Buddhism gradually adapted in Japan to the native spirituality. Even today Shinto elements are respectively strong in Japanese Buddhism. On the other hand, Christian population who believe in sole-(or mono-) God is less than $1 \%$.

\subsection{Korean Bibim Culture}

How about Korea? It is a bibim culture in a word. Korean Buddhism is called the Tongbulgyo (interpenetrated Buddhism). Korean Buddhist thinkers developed a new holistic approach to Buddhism. The main character of Tongbulgyo is to arrange different Buddhist doctrines and integrate them into one. While Chinese Buddhism has divided into many branches, Korean Buddhism has attempted to reconcile and harmonize them. Furthermore, Koreans adopted very actively Christianity.

Apparently incongruent food ingredients like vegetables, rice, hot pepper paste and sesame oil, etc. are mixed together into bibimbab. In the bibim culture there is one premise: that is, the gaze of oneness. It is an idea of viewing one between self and other or between subject and object. When we consider as one vegetables, rice, hot pepper paste, and sesame oil, only then can "bibim" be possible. They can be mixed. The

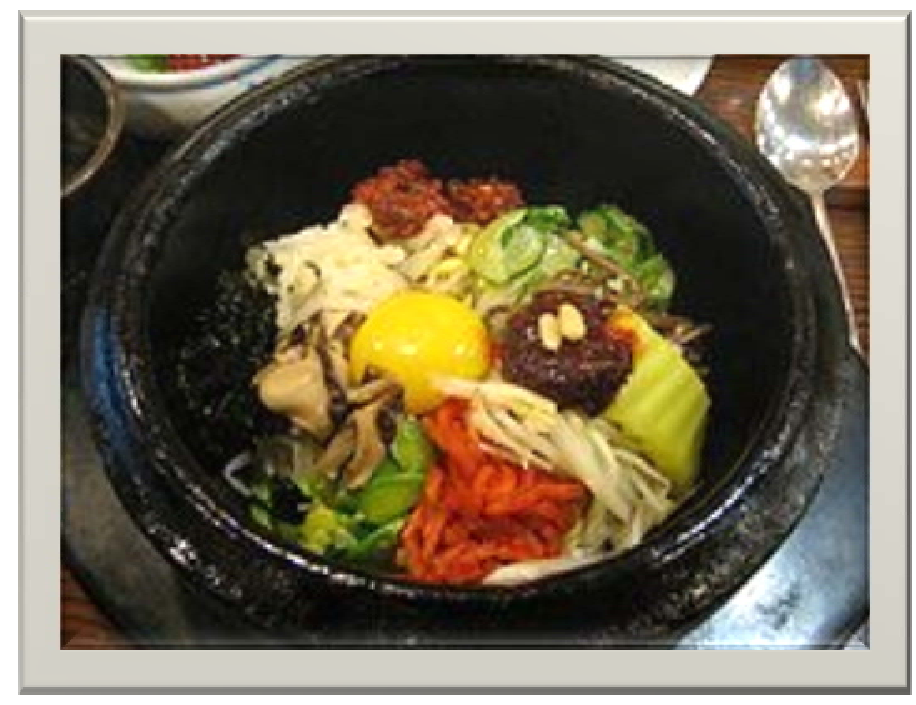

Fig. 1 Dolsot bibimbap.

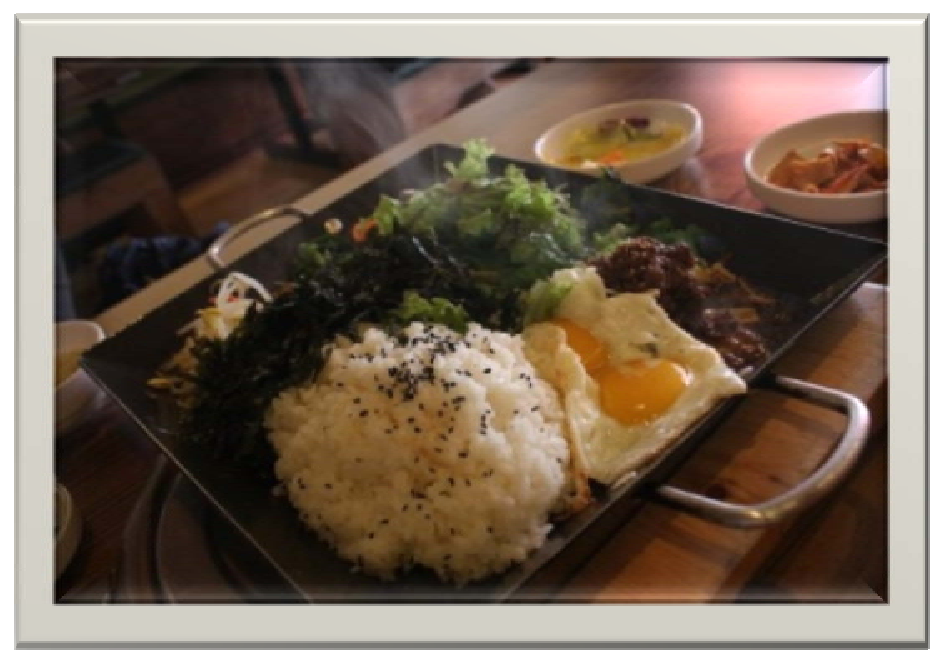

Fig. 2 Cheol-pan (iron plate) bibimbap. 
more mixed, the more they can get renewed. Through this bibim (mixing) process, they undergo fermentation. The original taste of each ingredient can be mingled, chemically acted and rise to a higher level of rank. Neither hot pepper paste, nor sesame oil, nor rice, but only the bibimbap taste comes out along the process of mixing. It is a result of good communication. Man and society should be mixed. Workers and management could not be separated. The leadership of "juste milieu" of the former conservative president Lee advocates is closely related to the logic of bibimbab.

\section{Conclusion: Food as a Cultural Exchange to Access Communication}

It is the course of nature that commercialized foods after modernity tend to be inexhaustibly evolved to please the taste of consumers and to lead it. Korean bibimbap we can meet today in New York, Tokyo and Beijing may stand on the top of this post-modern evolution. Dolsot (stone pot) bibimbap and cheol-pan (iron plate) bibimbap are very popular in Korean restaurants in New York. It is not so easy to enumerate one by one a very long list of bibimbaps from a classical bibimbap with boiled barley and young radish kimchi (Korean spicy pickled cabbage) into a new Meongge (Sea squirt sashimi) bibimbap.

However, there must be an unchangeable basic element in any biological or cultural evolutions. The core principle of making bibimbap is to mix steamed rice with assorted vegetables. If you fry rice and vegetables with perilla (wild sesame) oil on hot iron plate, ${ }^{8}$ it is not a bibimbap, but a bokkeumbap (Korean fried rice) or a chao fan (Chinese fried rice). If dolsot (stone pot) bibimbap is so hot, it becomes a stir-fried rice. The dolsot can be entitled as bibimbap, only on the condition that it gets cool before becoming

\footnotetext{
${ }^{8}$ Perilla is a genus of annual herb that is a member of the mint family.
}

fried or grilled. You can mix minced raw or roasted beef and assorted vegetables with soy sauce or hot pepper sauce, but the essence of bibimbap is in the delicate taste of rice. Today, Korean menus of longevity are the rice cooked with various cereals, cooked vegetables and hot pepper paste. The bibimbab is made of these kinds of three things. The bibimbab contains integration and community spirits.

As stated above, Japanese Genghis Khan cuisine is derived and evolved from nabe (one-pot cooking).As another example, shabu-shabu (boiled beef) is a Japanese variant of hot pot. It is also evolved from the Chinese hot pot known as "shuan yang rou (mutton)". It is known that a restaurant owner in Osaka developed it in 1952. When he served in the armed forces in Manchuria in the early 1940s, he then encountered shuan yang rou. After returning home, he developed a cooking brazier and boiled beef in it. It is a precursor of shabu-shabu. The shabu-shabu was interestingly named according to the "swish swish" sound of boiling soups.

The Chinese hot pot cooking for shuan yang rou is called "huo-guo". The huo-guo (hot pot) began to be popular during Qing dynasty, but the modern form of shuan yang rou Beijing people eat nowadays appeared with the spread of refrigerators. It was the middle 1990s that the shuan yang rou (of putting frozen sliced mutton in boiling soup) captivated the palate of Beijing people. Thanks to the success of reform and opening-up policy, Beijing people could afford to pay it, the shuan yang rou was well established as a winter custom of Beijing.

The Japanese sushi also became very popular with the advent of refrigerator. The sushi (すし) is closely related to fermented fish. It is also written as “鮨” and/or “䰻” in Chinese characters. They both mean the same thing: that is, fermented fish. The origin of fermented fish is in Southeast Asia (Thailand, Laos, and Vietnam). In hot countries keeping sources of protein like perishable fish is a huge problem. Necessity is the mother of invention. If you preserve 
salted fishes and shells with boiled grains, the lactobacillus in sour grain fermentation breaks down the protein in fish into basic units called amino acids. It preserves fishes from decay. It resembles closely to "Korean flatfish sweet drink made from fermented non-glutinous millet (가자미食䣿)”. In China there exists an opinion that Chinese people also made sushi, a vinegared rice with meat, fish and shell, and even insects in the Southern Song period. The sushi is well known for Japanese own food culture, but it shows Japanese great talent for borrowing foreign food culture and improving it in Japanese style. Today's sushi is no longer fermented, therefore quickly prepared. However, its maturing process is still considered important. It is not so difficult to understand why Japanese sushi specialists say "tsukeru sushi", instead of making sushi. The verb tsukeru (漬つける) means “soak in brine”.

It was only in 1930s that Japanese started to eat the modern form of sushi. A Japanese scholar Yoshikawa Seiji insisted that the origin of sushi was in the Thailand and the north part of Myanmar where people still preserve fish with grain and salt. It is very similar to the oldest form of sushi (narezushi). ${ }^{9}$ However, the original form of sushi often appeared on the Chinese old records. It was hai (醢) in Chinese. It exactly

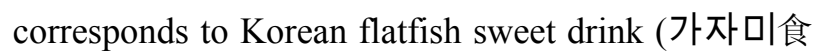
酤). Why did Yoshikawa seek the original form of narezushi in South-East Asia? Some Korean scholars insisted that the narezushi was originated in Korean flatfish sweet drink. That is, the origin of Japanese sushi was in Korea. Thus, Yoshikawa raised a strong reaction to this Korean imported theory and found the origin of narezushi in Winnan province in China and in South-East Asia. However, it was a real surprise for

\footnotetext{
${ }^{9}$ Nare-zushi was made of gutted fish stored in fermented rice for months at a time for preservation. The fermented rice was discarded and fish was the only part consumed. Funazushi (a rare type of narezushi) is still served near Lake Biva, Shiga Prefecture. It boasts a tradition that goes back 1,000 years.
}

some Korean chauvinistic scholars to find that the hai (䤀) which means Korean flatfish drink (食醢) appeared on the Chinese literature.

If Chinese are known as tofu people, Korean, as kimchi people. ${ }^{10}$ We cannot imagine Korean kimchi without hot pepper sauces, but chili pepper was introduced into Korea by the Japanese. Following the outbreak of the Japanese invasion of Korea (Imjin war) in 1592, many Japanese soldiers of the Honshu (mainland) rushed into Korea. Meantime, chili pepper came into the Korean peninsula along long lines of refugees. Thus, a Korean scholar Su-gwang Yi (1563-1628) first wrote it calling it "Japanese mustard (倭芥子)" in his Jibong-Yusol (the earliest Korean Encyclopedia) in 1614. However, Japanese oppositely believed that chili pepper was handed down to Japan by way of Chosun (old Korea). According to the Yamato Honzo (大和本草) in 1708 by the Confucian scholar and herbalist Kaibara Ekken (貝原益軒) (1630-1714), ${ }^{11}$ chili pepper was introduced into Japan from Korea, when Toyotomi Hydeyoshi (1536-1598) attacked Chosun. Therefore, it was called "Koryo pepper (高麗胡椒)”. In those days, Japanese society was divided into several han systems (feudal domains), so almost incapable of integrating each district's news into Japanese central government. ${ }^{12}$ Japanese did not recognize for a long time that chili pepper which traveled to Chosun from Nagasaki by way of Tsushima returned to Honshu! Even today, Japanese call it “Tang mustard (togarashi•唐辛子・蕃椒)”. “To (唐)" symbolizes old China and Korea.

The discussion on the "origin" of the food as a product of cultural exchange is meaningless. There are conflicting opinions on the origin of Korean bibimbaps. Contrary to public opinion "bibimbab is a

\footnotetext{
${ }^{10}$ Kimchi is a traditional fermented Korean dish made of vegetables with a variety of seasonings.

${ }^{11}$ It was in fact a Japanese version of a Ming model Honzo Komoku (本草綱目) (1590).

12 Thehan (藩) or domain was the name of the estate belonging to a warrior in Japan after the 17th century. The fiefs of the daimyos of the samurai class of Japan during the Edo period were called han.
} 
kind of royal court dish", a Korean scholar insisted that the Jonju bibimbap was derived from a humble market food consumed by poor working class. ${ }^{13}$ Many Jonju people were disappointed with his convincing hypothesis, but there is no historical document on it. Is it reasonable to decide which parts will be maintained as heritage in the form of tradition and history and which parts must be cut by some form of Procrustean bed? Should we rewrite Korean historical books in order to say that the Jonju bibimbap was served on the royal table? On the other hand, some Korean conservatives tend to call the classical bibimbap in a brassware (yugi in Korean) a "tradition", but the dolsot bibimbap as an evolved form of bibimbap, "a fake". But both yugi and dolsot bibimbap should coexist, and thereafter various bibimbaps should be developed as many as possible.

If you would live, just eat soybeans! Nowadays, the global parade of tofu continues without break. An American actress Gwyneth Paltrow presented tofu as one of her favorite diet foods in the Oprah Winfrey show. Tofu was also regularly served on the table at the White House during the Clinton administration. Tofu, as a Cinderella of Chinese origin, became an icon of millions of people in the world, beyond Asia. Food is constantly evolving as a product of cultural exchange. We do not eat food in arguing on its legitimacy or history. Our pleasure of eating depends on the individual taste; therefore, it is not necessary to play a "trick" on a precious food like a source of the life, in the name of legitimacy or of history (nationalism or gastro-racism). By contrast, I would like to give a compliment to the self-evolving post-modern bibimbap, here and there in the Global village. ${ }^{14}$

\footnotetext{
13 The city of Jonju, the capital of the North Jolla Province of South Korea, is famous throughout the nation for its version of bibimbap

${ }^{14}$ This paper is primarily based on the research works of the Korean food anthropologist Young-ha Joo.
}

\section{References}

[1] Takao, I. et al. 2009. "The Riffle Effects of Genghis Khan Barbecue Cuisine on Hokkaido's Economy." Journal of Case Research in Business and Economics.

[2] Akira, S. 2010. "Meat-Eating in the Kojimachi District of Edo." In Japanese Food ways, Past and Present, edited by Eric C. Rath and Stephanie Assmann. Chicago and Springfield: University of Illinois Press Urbana, 92.

[3] Naomichi, I. 2001. The History and Culture of Japanese Food. Routledge.

[4] Katarzyna J. C. 2006. Modern Japanese Cuisine Food, Power and National Identity. Reaktion Books.

[5] 2018. "Genghis Khan Conquers Japanese Palates." Food Forum.

http://www.kikkoman.com/foodforum/spotlightjapan/03.s html.

[6] 2007. History of Tofu. Lafayette, California: Soyinfo Center. http://www.soyinfocenter.com/HSS/tofu1.php.

[7] Shinoda, O. 1971. "Doufu Kao (The Study of Tofu)." In Zhongguo Doufu (Tofu in China), edited by Lin Haiyin. Taipei: Chun Wenxue Chubanshe, 41.

[8] Chen, W. 1991. "Doufu Qiyuan Yu Heshi (When was the origin of beabcurd)?" Nongyue Kaogu (Archaeology of Agriculture).

[9] Tan, C.-E. 2008. "Tofu and Related Products in Chinese Food Ways." In The World of Soy, edited by Christine M. du Bois, Chee-Beng Tan, and Sidney Mintz. University of Illinois, 42.

[10] Hobsbawm, E., and Ranger, T., eds. 1983. The Invention of Tradition. Cambridge University Press. 